\title{
ЛИТЕРАТУРОВЕДЕНИЕ
}

УДК 398.9(=161.1)(571.54)

DOI: $10.18101 / 2305-459 X-2020-2-46-52$

\section{ЦВЕТОВАЯ СИМВОЛИКА И МИСТИЧЕСКИЕ МОТИВЫ ПОЭЗИИ В. Ф. ХОДАСЕВИЧА}

\author{
(c) Александров Илья Алексеевич \\ кандидат филологических наук, доцент, \\ Московский гуманитарный университет \\ Россия, 111395 , г. Москва, ул. Юности, 5 \\ aleks-ilia91@yandex.ru
}

\begin{abstract}
Аннотация. В статье рассматривается роль цветовой символики в поэзии В. Ходасевича. В частности, уделяется внимание мистическим мотивам, имеющим, с одной стороны, символистский генезис, с другой стороны, органически вплетающимся в более позднюю, неоклассицистическую канву текстов. Доказывается, что цветовая фактура образа, связанная чаще всего с областью повседневности, быта и выраженная различными цветовыми эпитетами, является важным зрительным маркером перехода в мистическое пространство или выхода из него (рассмотрено на примере стихотворений «В Петровском парке», «Смоленский рынок», «Эпизод», «2 ноября»). Предполагается, что цвет может быть рассмотрен как средство интеграции символического и предметно-объектного начала в поэтических текстах В. Ходасевича. При этом стихотворения «Музыка» и «Баллада» также рассматриваются как произведения, имеющие мистический сюжет духовного преображения.
\end{abstract}

Ключевые слова: В. Ходасевич; мистика; символизм; неоклассицизм; сигнал; цветовой эпитет; мотив; будничность.

Для цитирования:

Александров И. A. Цветовая символика и мистические мотивы поэзии В. Ф. Ходасевича // Вестник Бурятского государственного университета. Язык. Литература. Культура. 2020. Вып. 2. С. 46-52.

Представление о В. Ф. Ходасевиче как о поэте, прошедшем путь от символизма к неоклассицизму, достаточно прочно укоренилось в литературоведении. Такая общая для разных научных школ и направлений рецепция совпадает с пониманием В. Ходасевича как поэта большой творческой эволюции: разница в уровне художественного совершенства ранних сборников «Молодость», «Счастливый домик», во многом подражательных, и поздней книги «Тяжелая лира»велика. Вместе с тем чрезвычайно важно не сводить со счетов его первые символистские стихотворения. Акцентировка, намеренное «заострение» родовых признаков символизма стало школой для молодого поэта и позволило в дальнейшем сформировать неоклассицистический облик позднего творчества, рафинировать неоклассицистическую форму образов и мотивов.

Чрезвычайно оригинальными и важными примерами подобного «заострения» является использование мистических мотивов. Роль таких художественных средств значительна: еще Д. П. Святополк-Мирский назвал ее самой отличитель- 
ной чертой В. Ходасевича и говорил, что он «единственный из всех молодых поэтов - мистик» [5, с. 721-722], определяя при этом мистичность главным фактором его популярности у современников. Логично предположить, что с течением времени поэт должен был отказаться от мистики как от ненужной символистской атрибутики. Однако С. Г. Бочаров справедливо замечает, что и поздние стихотворения («Как птица в воздухе...», «Улика», «Автомобиль») и программное стихотворение «Путем зерна», в котором зерно - «символ мистической смерти и нового рождения» [3], неоклассицистические по форме, далекие от символизма, также содержат мистическое. Следовательно, мистика - постоянная часть эстетических поисков В. Ходасевича, неизменный объект его творчества. Н. М. Солнцева справедливо отмечает традиционность В. Ходасевича, что в то же время не «означало отказа от сочетания классических и новых форм» [6, с. 176].

Остается неясным, с какими иветовыми художественными решениями они были связаны, как цветовой символизм раскрывался в ранних и поздних текстах.

Стихотворение «Сны» репрезентует архетипное представление о снах как о путешествиях души человека в иной мир. Типичная для В. Ходасевича ирония, открывающая текст, строится на антитезе низкого и высокого («одежда», «пол» - «душа», «страдать»), в равной степени важных для последующего развития сюжета. Адресация послания душе выражается императивной формой «ступай»:

Так! наконец-то мы в своих владеньях!

Одежду —на пол, тело — на кровать.

Ступай, душа, в безбрежных сновиденьях

Томиться и страдать! [8, с. 46].

Во второй строфе императивность усилится, и глагол «бреди» будет построен на повторе («бреди», «бреди»). Такой прием имитирует стилистику заклинания - загадочным образом «душа» преобразуется в «дух», который на протяжении последующих четырех строф совершит путешествие в «иной предел». Герой дистанцируется от этого «духа» («Где ты — не я»), и в этом угадывается романтическая мотивировка, т. к. именно «иной предел» оказывается местом свободы ${ }^{1}$ («Свободен ты»). Последующее возвращение к земному существованию закольцовывает композицию, что выражает предопределенность попыток уйти от бренности земной жизни («День изо дня, в миг пробужденья трудный...»). Незначительная, на первый взгляд, пейзажная деталь имеет символическое цветовое выражение, служит маркером безысходной земной жизни («Смотрю в окно и вижу серый, скудный / Мой небосклон...»). Поэтому в завершающем четверостишии автор разворачивает пейзаж в подчеркнуто будничном ключе («Все тот же двор, и мглистый, и суровый, / И голубей, танцующих на нем...»). При этом в данном контексте эпитеты «мглистый», «суровый» символизируют повседнев-

\footnotetext{
${ }^{1}$ Стоит отметить грамматическую традиционность, классичность формы, которая по сути является романтическим клише, восходящем к традиции «школы гармонической точности». Потенциально она способна встречаться в «разнообразных контекстах и рамках различных лирических сюжетов» [10].
} 
ность, далекую от свободы. Парадоксально, что у наследника символизма В. Ходасевича цветовые эпитеты, содержащие повседневно-прозаический подтекст, выражают уход от мистического мира «вещего сна».

Несколько иной - на границе символического и реалистического - цветовая фактура представлена в более поздних текстах — «В Петровском парке» и «Смоленском рынке».

В поражающем натуралистичностью стихотворении «Петровский парк», по своей манере подачей фактов напоминающем заметку, цветопись также становится выражением будничного. В основе - описание повешенного на дереве человека («видел это весной 1914 г., на рассвете, возвращаясь с $\mathrm{A}<$ нной> И<вановной> и Игорем Терентьевым из ночного ресторана в Петр <овском $>$ Парке» [1, с. 681]). Холодная невовлеченность героя создает в лирическом тексте эпическую дистанцию, которая позволяет детализировать образ и сделать его максимально зримым:

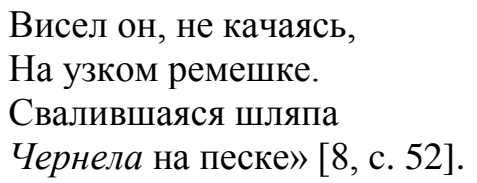

Ремешок - символ смерти - становится зримым атрибутом покойного, поэтому автор обращается к нему и в первой, и в заключительной строфе. Как следствие, эпитет «черный» имеет подтекст смерти. Иными словами, цветовая деталь, символически ассоциируемая со смертью, является частью реалистического плана.

Сюжет «Смоленского рынка» строится на будничной встрече лирического героя с покойным. Стилистически текст восходит к «Гаданию», написанному в 1907 г. Уже в «Гадании» вхождение в мир мистики отмечено краснылм цветом: «Свеча колеблет пламя красное. / Мой рок! Лицо приблизь ко мне!» [9, с. 13]. Образный ряд частично перенесется затем в «Смоленский рынок» (свеча, гроб). В «Смоленском рынке» отстраненная созерцательность, медитативность («Смоленский рынок / Перехожу / Полет снежинок / Слежу, слежу» [8, с. 53] переходят в мистическую ассимиляцию смерти, подпитанную несколько игровым чувством обреченности («Все те же встречи / Гнетут меня / Все к той же чаше/припал и пью») ${ }^{1}$. Желтый цвет по-достоевски выступает символом перехода в это состояние («желтеют свечи»). Семантикой смерти наполнен эпитет «синий» («синий гроб»), стилистически органичный картине московской зимы. Фофановский контекст стихотворения, отмеченный Н. А. Богомоловым (реминисценции на стихотворение «Что наша вечность?»), преломлен в финале. В отличие от К. Фофанова, герой В. Ходасевича не видит безысходности во встрече со смертью, трансформируя чувство обреченности

\footnotetext{
${ }^{1}$ Н. Солнцева отмечает, что в стихах «Молодости» «минорность, недоговоренность, неудовлетворенность - цитаты из символистского поэтического словаря, эхо модных мотивов "праха и тлена"» [6, с. 173]. Как можно убедиться, такие мотивы останутся актуальными и позднее.
} 
в продуктивную модель преображения мира («Преобразись, / Смоленский рынок!»).

Таким образом, бытовая, повседневная встреча с нереальным (неживым, потусторонним) миром сопровождается цветовым знаком, атрибутом перехода в другой мир или выхода из него. В этом символистское решение, вплетающееся в неоклассицистическую ткань текста.

Целую серию сюжетов внутренней метаморфозы героя силой «неясного струения», музыки, скрытой силы открывает стихотворение с подчеркнуто прозаичным названием «Эпизод». В нем мистический план связан с пушкинским контекстом и выражен образом «маски Пушкина, закрывшего глаза», углублен шестистопным ямбом белого стиха. В свете такого образа цветовую деталь интерьера - «желтые обои» - возможно рассматривать как атрибут мистического изменения человека. В контексте истории русской литературы желтый - цвет негативных коннотаций (Ф. М. Достоевский, И. Ф. Анненский, М. А. Булгаков и т. д.) - болезни, бедности, смерти. В данном случае он выражает процесс трансформации, тяжелого переходного процесса:

\author{
Какое-то неясное струенье \\ Бежало трепетно и непрерывно - \\ И, выбежав из пальцев, длилось дальше, \\ Уж вне меня. Я сознавал, что нужно \\ Остановить его, сдержать в себе, — но воля \\ Меня покинула... Бессмысленно смотрел я \\ На полку книг, на желтые обои, \\ На маску Пушкина, закрывшую глаза... [8, с. 56].
}

Таким образом, желтый цвет здесь наделяется, с одной стороны, символическим смыслом; с другой стороны, оказывается очень традиционным, классическим приемом, имеющим при этом зримый, предметный характер.

В явную перекличку - и на уровне ритмического рисунка, и на уровне сюжета, мотивов - с «Эпизодом» вступает стихотворение «2 ноября». Оно также имеет пушкинский контекст, совпадает в названии с пушкинским стихотворением. В. Ходасевич рисует картину возвращающейся к жизни после длительного ненастья Москвы. Постепенное восстановление жизни - тяжелый болезненный процесс - символически выражено пейзажной деталью: «Желтым оком / Ноябрьское негреющее солнце / Смотрело вниз...» [8, с. 62]. Чудесное оживление сродни воскресению, и этим пониманием мотивирован выходящий за временные рамки пасхальный мотив в конце первой строфы («...На кладбище москвич благочестивый / Ходил на Пасхе - красное яичко / Съесть на могиле брата или кума...»). Неожиданным, но также объяснимым с точки зрения дихотомии «жизнь/смерть», «умирание/оживление» оказывается и образ гроба, который в канве московского текста, топонимического пространственного (у А. Пушкина маршрут Адриана Прохорова соединяет отдаленные друг от друга районы - Басманную и Никитскую, у Ходасевича люди бредут «из конца в конец / от Пресненской заставы до Рогожской / И с 
Балчуга в Лефортово») отсылает к «Гробовщику» А. Пушкина ${ }^{1}$. Герой стихотворения обращает внимание на красный цвет гроба. Упомянутое кладбище, «желтое око негреющего солнца», красный цвет гроба - символические медиаторы, цвета-сигналы мистического воскресения Москвы в неоклассицистическом тексте.

Стремлении к фиксации будничности - родовой признак В. Ходасевичанеоклассициста. По словам Н. А. Богомолова, «мистика объективируется и выглядит такой же естественной, как поход к другу (сюжет стихотворения «2 ноября». - прим. И. А.) или попытка разобрать на дрова заброшенный московский дом» [1, с. 16-17]. В «Музыке», например, герой за колкой дров внезапно становится причастным к тайнам небесной игры виолончели и арфы. Такая объективация тем не менее не исключает границу между мистическим и реальным. Фигура соседа Сергея Иваныча (разговорная форма функциональна) олицетворяет часть реальности, не способной соединиться с необъяснимым. Переход через границу будничного и сверхъестественного хорошо продемонстрирован в стихотворении «Автомобиль». Наречие «вдруг» в начале третьей строки вырывает героя из дремоты. Сюжетная перипетия - появление автомобиля - ознаменована черным цветом. Цветовой эпитет также сигнализирует о мистическом. «Реальный» черный цвет метафизически контрастирует с белым цветом ангельских крыльев. Живописный контраст символически перекликается с антитезой будничного и мистического, зримое появление которого преображает объект из мира «здесь и сейчас»:

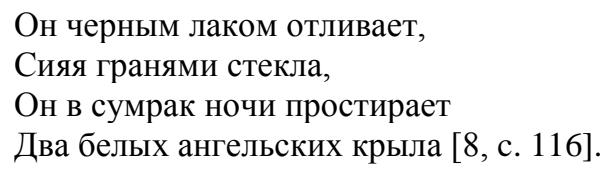

«Баллада» - апофеоз преображения жизни через творческое начало - логическое продолжение «Музыки». Здесь идея углубляется путем экстатического воздействия искусства, имеющего такую же, как и в «Музыке», загадочную и не содержащую понятных первоистоков природу. Результат такого влияния приводит к полной трансформации мира, и такая ситуация требует выражения пластическими средствами. Завершение метаморфозы в последней строфе ассоциируется с черным цветом:

«На гладкие черные скалы / Стопы опирает - Орфей» [8, с. 133]. Указание на державинскую первооснову цветового образа ${ }^{2}$ справедливо, однако

\footnotetext{
${ }^{1}$ Очевидную значимость имеют и автобиографические контексты. С. И. Кормилов в своей статье «Москва в поэзии В. Ходасевича» достаточно подробно освещает феномен «московского текста» В. Ходасевича, указывает на автобиографизм лирического героя: «Автобиографический герой посещает знакомого столяра, изготовляющего красный гроб» [4, с. 86].

2 Строки «Пятою черны бездны давит, / Чело касается звездам» связаны не только с восьмой строфой «Баллады», но и - благодаря цветовой характеристике - с гладкими черными скалами из предпоследней строки стихотворения Г. Р. Державина «Лирик» (см. в исследовании П. Ф. Успенского [7]).
} 
понимание такой реминисценции, как «клавиши» интертекстуальной клавиатуры, не определяет конечную функцию живописной детали, которая, пусть и не имея символистской основы, является цветом-сигналом мистического процесса.

Несомненно, в будущем стоит полнее разобраться в органике мистических мотивов поэзии В. Ходасевича. Однако прояснение их пластической природы сводится к тому, что цветовая фактура зачастую служит сигналом, важным атрибутом формирования мистического мотива, является своеобразным «символистским» медиатором в неоклассицистической канве текста.

Литература

1. Богомолов Н. А. Жизнь и поэзия Владислава Ходасевича // В. Ходасевич. Стихотворения (Библиотека поэта. Большая серия). Л., 1989. С. 507.

2. Богомолов Н. А. Комментарии // Ходасевич В. Ф. Европейская ночь. Стихотворения. Воспоминания. М.: Эксмо, 2013. 734 с.

3. Бочаров С. Г. «Памятник» Ходасевича [Электронный pecypc]. URL: http://hodasevich.lit-info.ru/hodasevich/kritika/bocharov-pamyatnik.htm (дата обращения: 10.06.2020).

4. Кормилов С. И. Москва в поэзии Владислава Ходасевича // Вестник Московского университета. 2011. № 3. С. 84-93.

5. Святополк-Мирский Д. П. История русской литературы. Новосибирск: Свиньин и сыновья, 2009. 872 с.

6. Солнцева Н. М. Поэзия В. Ф. Ходасевича: от символизма к неоклассицизму // Знание. Понимание. Умение. 2012. № 2. С. 173-178

7. Успенский П. Ф. «Лиры лабиринт»: почему В. Ф. Ходасевич назвал четвертую книгу стихов «Тяжелая лира» // Лотмановский сборник. 2014. № 4. С. 450-467.

8. Ходасевич В. Ф. Европейская ночь. Стихотворения. Воспоминания. М.: Эксмо, 2013. $734 \mathrm{c}$.

9. Ходасевич В. Собрание стихов. Т. I. La Presse Libre. Париж, 1982. 311 с.

10. Щеглов Ю.К. Проза. Поэзия. Поэтика. Избранные работы [Электронный ресурс]. URL: https://iknigi.net/avtor-yuriy-scheglov/96589-proza-poeziya-poetika-izbrannye-rabotyyuriy-scheglov/read/page-10.html (дата обращения: 10.06.2020).

\section{COLOR SYMBOLS AND MYSTICAL MOTIVES IN V. F. KHODASEVICH'S POETRY}

\section{Ilya A. Aleksandrov}

Cand. Sci. (Phil.), A/Prof.,

Moscow University for the Humanities

5 Yunosti St., Moscow 111395, Russia

aleks-ilia91@yandex.ru

Abstract. The article deals with the role of color symbolism in V. Khodasevich's poetry. In particular, attention is paid to mystical motives, which, on the one hand, have a symbolist genesis, and on the other hand, get involved in the later neoclassical outline of the texts. It is proved that the color texture of the image, most often being associated with the everyday life, and expressed by various color epithets, is an important visual marker of the transition to the mystical space or going out of it (evident from the poems "In Petrovsky Park", "Smolensk Market", "Episode", "November 2"). It is assumed that color can be regarded as a means of integrating the symbolic and subject-object principles in V. Khodasevich's poetic 
texts. At the same time, the poems "Music" and "Ballad" are also considered as works with a mystical plot of spiritual transformation.

Keywords: V. Khodasevich; mysticism; symbolism; neoclassicism; signal; color epithet; motive; everyday life. 